\title{
Effect of Phosphorus Management through Rock Phosphate Application to Preceding Crops on Soil Enzymes and Microbial Biomass in Organic Cultivation of Groundnut
}

\author{
Mallesha* and Satyanarayana Rao \\ Department of Agronomy, University of Agricultural Sciences, \\ Raichur, Karnataka-584104, India \\ *Corresponding author
}

\section{A B S T R A C T}

\begin{tabular}{|l|}
\hline Key w or d s \\
Rock phosphate, \\
Sunhemp, \\
Preceding crops, \\
Bajra. \\
\hline Article Info \\
\hline Accepted: \\
04 July 2017 \\
Available Online: \\
10 September 2017 \\
\hline
\end{tabular}

Field experiment was carried out during 2014-15 and 2015-16 at Main Agricultural Research Station, UAS, Raichur to study the impact of varied levels of rock phosphate application to preceding sunhemp and bajra crops on growth and yield of groundnut (Arachis hypogaea L.). The two years pooled data indicated that soil application of rock phosphate @ $200 \mathrm{~kg} \mathrm{ha}^{-1}$ to the preceding sunhemp recorded significantly higher dehydrogenase activity in soil $\left(16.1 \mu \mathrm{g}\right.$ TPF $\mathrm{g}^{-1}$ soil day $\left.{ }^{-1}\right)$ and phosphatase activity (73.24 $\mu \mathrm{g}$ PNP $\mathrm{g}^{-1}$ soil $\left.\mathrm{hr}^{-1}\right)$. Soil application of rock phosphate @ 150 to $200 \mathrm{ka}$ $\mathrm{ha}^{-1}$ to preceding sunhemp recorded higher microbial population of actinomycetes, fungi and nitrogen fixer's. The phosphorus solubilizers' population found significant with application of RDF + FYM.

\section{Introduction}

Rock phosphate is an important sources of phosphorus and soil amendment that is permitted to use in organic production systems. It is a naturally occurring mineral source of insoluble phosphate and is much less expensive than soluble phosphatic fertilizers. Among the organic nutrient sources that are used in organic production system rock phosphate contains higher quantity of phosphorus. The residual effect of rock phosphate application on succeeding crops is also distinct. Nazeer and Mohammed (2014) reported that application Hazara rock phosphate (HRP) in wheat-maize system produced a significant residual effect on grain and biomass yield of maize. The variations induced by levels of HRP were mostly similar while the residual levels showed better results in terms of yield and yield components for higher doses compared to lower doses in succeeding maize.

\section{Materials and Methods}

A field experiment was conducted to study the effect of phosphorus management through rock phosphate application to preceding crops in organic cultivation of groundnut at Main Agricultural Research Station, University of Agricultural Sciences, Raichur, during kharif 
and rabi seasons of 2014-15 and 2015-16. The soil of the experimental site was sandy clay loam in texture with bulk density of 1.34 $\mathrm{g}$ per $\mathrm{cc}, \mathrm{pH}$ of 7.75 with organic carbon content of $0.43 \%$. The soils were low in available $\mathrm{N}(272.2 \mathrm{~kg} / \mathrm{ha})$ and available $\mathrm{P}_{2} \mathrm{O}_{5}$ $\left(32.5 \mathrm{~kg} \mathrm{ha}^{-1}\right)$ and medium in available $\mathrm{K}_{2} \mathrm{O}$ $\left(292.4 \mathrm{~kg} \mathrm{ha}^{-1}\right)$. The treatments consisted of four levels of rock phosphate 50, 100, 150 and $200 \mathrm{~kg} \mathrm{ha}^{-1}$ applied to two preceding crops bajra and sunhemp. The treatment with RDF + FYM applied for bajra and groundnut in the system. Bajra and sunhemp taken during kharif and succeeding groundnut was sown during rabi season. All the organic treatments received recommended dose of nitrogen through compost and vermicompost (50:50). At the time of sowing, recommended dose of fertilizer for bajra $50: 25: 0 \mathrm{~kg} \mathrm{~N}$ : $\mathrm{P}_{2} \mathrm{O}_{5}: \mathrm{K}_{2} \mathrm{O}$ ha $^{-1}$ and for groundnut $25: 75: 25 \mathrm{~kg}$ $\mathrm{N}$ : $\mathrm{P}_{2} \mathrm{O}_{5}: \mathrm{K}_{2} \mathrm{O}$ ha $^{-1}$ was applied in $\mathrm{RDF}+$ FYM treatment and remaining organic treatments received $\mathrm{N}$ through Compost and vermicompost (50:50). Mussoorie rock phosphate along with Phosphate Solubilising Bacteria (PSB) was applied to preceding crops in Kharif as per the treatments. The experiment was laid out in RCBD with three replications.

The initial soil microbial population like actinomycetes, fungi, $\mathrm{N}$ fixer's and Phosphorus solubilizers $\left(12.2 \times 10^{3} \mathrm{CFU} \mathrm{g}^{-1}\right.$ of soil, $14.3 \times 10^{4} \mathrm{CFU} \mathrm{g}^{-1}$ of soil, $22.4 \times 10^{3}$ CFU g ${ }^{-1}$ of soil and $11.2 \times 10^{3} \mathrm{CFU} \mathrm{g}^{-1}$ of soil, respectively) in experimental site were analysed with the serial dilution plate count technique (Pramer and Schmidt, 1964).

The initial soil dehydrogenase activity (3.80 $\mu \mathrm{g}$ TPF $\mathrm{g}^{-1}$ soil $\mathrm{h}^{-1}$ ) was determined the procedure as described by Casida et al., (1964). Initial soil status of phosphatase activity $\left(0.91 \mu \mathrm{g}\right.$ PNP $\mathrm{g}^{-1}$ soil $\left.\mathrm{h}^{-1}\right)$ was determined by following the procedure of Evazi and Tabatabai (1979).

\section{Results and Discussion}

\section{Soil enzymatic activity}

The preceding sunhemp and bajra crops with different levels of rock phosphate application significantly influenced dehydrogenase and phosphatase activity in soil. Application of rock phosphate @ $200 \mathrm{~kg} \mathrm{ha}^{-1}$ to the preceding sunhemp recorded significantly higher dehydrogenase activity in soil $(16.1 \mu \mathrm{g}$ TPF $\mathrm{g}^{-1}$ soil day ${ }^{-1}$ ) which in turn was found on par with rock phosphate application @ 50, 100 and $150 \mathrm{~kg} \mathrm{ha}^{-1}$ to the preceding sunhemp (14.8, 14.8 and $15.5 \mu \mathrm{g}$ TPF g ${ }^{-1}$ soil day $\left.{ }^{-1}\right)$ and rock phosphate application @ $200 \mathrm{~kg} \mathrm{ha}^{-1}$ to the preceding bajra crop $\left(14.7 \mu \mathrm{g}\right.$ TPF $\mathrm{g}^{-1}$ soil day $^{-1}$ ) and RDF + FYM to both the crops $\left(15.3 \mu \mathrm{g}\right.$ TPF $\mathrm{g}^{-1}$ soil day $\left.^{-1}\right)$. Significantly lower dehydrogenase activity in the soil was recorded with treatment receiving rock phosphate @ $50 \mathrm{~kg} \mathrm{ha}^{-1}$ to the preceding bajra crop $\left(11.5 \mu \mathrm{g}\right.$ TPF $\mathrm{g}^{-1}$ soil day $\left.{ }^{-1}\right)$.

Significantly higher phosphatise activity in the soil was recorded with rock phosphate @ $200 \mathrm{~kg} \mathrm{ha}^{-1}$ to the preceding sunhemp (73.24 $\mu \mathrm{g}$ PNP $\mathrm{g}^{-1}$ soil $\mathrm{hr}^{-1}$ ) and it was on par with rest of all the treatments except rock phosphate@ @ 50 and $100 \mathrm{~kg} \mathrm{ha}^{-1}$ to the preceding bajra crop (55.03 and $62.48 \mu \mathrm{g}$ PNP $\mathrm{g}^{-1}$ soil $\mathrm{hr}^{-1}$ ). The higher enzymatic activity with these treatments was due to higher amounts of root exudates of crops and favourable rhizosphere environment (Table 1).

\section{Soil microbial population}

Actinomycetes population was found significant with application of rock phosphate @ $200 \mathrm{~kg} \mathrm{ha}^{-1}$ to the preceding sunhemp $\left(36.51 \times 10^{3} \mathrm{CFU} \mathrm{g}^{-1}\right.$ soil $)$ and it was on par with rock phosphate application @ $150 \mathrm{~kg} \mathrm{ha}^{-1}$ to preceding sunhemp and the treatment receiving $\mathrm{RDF}+\mathrm{FYM}$ to both the crops $\left(34.85 \times 10^{3} \mathrm{CFU} \mathrm{g}^{-1}\right.$ soil $)$. 
Table.1 Enzymatic activity and microbial biomass of soil at 90 days after sowing as influenced by phosphorus management through levels of rock phosphate to preceding crops (Pooled data of 2014-15 and 2015-16)

\begin{tabular}{|c|c|c|c|c|c|c|}
\hline Treatments & $\begin{array}{c}\text { Dehydrogenase } \\
\text { activity } \\
(\mu \mathrm{gPF} \\
{\text { formed } \mathrm{g}^{-1} \text { of }}^{-1} \text { ) } \\
\text { soil day }^{\text {a }} \text { ) }\end{array}$ & $\begin{array}{l}\text { Phosphatase } \\
\text { activity } \\
(\mu \mathrm{g} \text { PNP } \\
\text { released } \mathrm{g}^{-1} \text { of } \\
{\left.\text { soil } \mathrm{h}^{-1}\right)}^{-1}\end{array}$ & $\begin{array}{c}\text { Actinomycetes } \\
\text { (No. } \times 10^{3} \mathrm{CFU} \\
\mathrm{g}^{-1} \text { of soil) }\end{array}$ & $\begin{array}{c}\text { Fungi } \\
\left(\text { No. } \times 10^{4} \mathrm{CFU}\right. \\
\left.\mathrm{g}^{-1} \text { of soil }\right)\end{array}$ & $\begin{array}{c}\text { Free living } \\
\text { nitrogen fixers } \\
\text { (No. } \times 10^{3} \mathrm{CFU} \\
\mathrm{g}^{-1} \text { of soil) }\end{array}$ & $\begin{array}{c}\text { Phosphorus } \\
\text { solubilizers } \\
\text { (No. } \times \mathbf{1 0}^{\mathbf{3}} \mathrm{CFU} \\
\mathbf{g}^{-1} \text { of soil) }\end{array}$ \\
\hline $\begin{array}{l}\mathrm{T}_{1}: \mathrm{RP} @ 50 \mathrm{~kg} \mathrm{ha}^{-1} \text { to } \\
\text { preceding sunhemp }\end{array}$ & 14.79 & 70.39 & 30.21 & 30.35 & 41.35 & 24.64 \\
\hline $\begin{array}{l}\mathrm{T}_{2}: \mathrm{RP} @ 100 \mathrm{~kg} \mathrm{ha}^{-1} \text { to } \\
\text { preceding sunhemp }\end{array}$ & 14.85 & 71.00 & 32.90 & 31.93 & 41.57 & 23.55 \\
\hline $\begin{array}{l}\mathrm{T}_{3}: \mathrm{RP} @ 150 \mathrm{~kg} \mathrm{ha}^{-1} \text { to } \\
\text { preceding sunhemp }\end{array}$ & 15.50 & 72.50 & 35.05 & 33.79 & 51.23 & 20.46 \\
\hline $\begin{array}{l}\mathrm{T}_{4}: \mathrm{RP} @ 200 \mathrm{~kg} \mathrm{ha}^{-1} \text { to } \\
\text { preceding sunhemp }\end{array}$ & 16.06 & 73.24 & 36.51 & 34.68 & 53.23 & 20.87 \\
\hline $\begin{array}{l}\mathrm{T}_{5}: \mathrm{RP} @ 50 \mathrm{~kg} \mathrm{ha}^{-1} \text { to } \\
\text { preceding bajra }\end{array}$ & 11.52 & 55.03 & 26.58 & 25.80 & 34.81 & 21.89 \\
\hline $\begin{array}{l}\mathrm{T}_{6}: \mathrm{RP} @ 100 \mathrm{~kg} \mathrm{ha}^{-1} \text { to } \\
\text { preceding bajra }\end{array}$ & 13.54 & 62.48 & 29.53 & 29.20 & 36.72 & 20.57 \\
\hline $\begin{array}{l}\mathrm{T}_{7}: \mathrm{RP} @ 150 \mathrm{~kg} \mathrm{ha}^{-1} \text { to } \\
\text { preceding bajra }\end{array}$ & 13.89 & 68.96 & 30.59 & 29.58 & 37.34 & 19.01 \\
\hline $\begin{array}{l}\mathrm{T}_{8}: \mathrm{RP} @ 200 \mathrm{~kg} \mathrm{ha}^{-1} \text { to } \\
\text { preceding bajra }\end{array}$ & 14.69 & 70.18 & 31.20 & 29.80 & 40.89 & 17.54 \\
\hline $\mathrm{T}_{9}: \mathrm{RDF}+\mathrm{FYM}$ & 15.34 & 71.17 & 34.85 & 33.64 & 50.08 & 26.92 \\
\hline S. Em \pm & 0.47 & 2.03 & 1.13 & 0.91 & 3.11 & 0.86 \\
\hline C. D. at $5 \%$ & 1.40 & 6.08 & 3.37 & 2.73 & 9.32 & 2.58 \\
\hline
\end{tabular}


Treatment received with rock phosphate @ $200 \mathrm{~kg} \mathrm{ha}^{-1}$ to the preceding sunhemp recorded significantly higher number of fungal colonies $\left(34.68 \times 10^{4} \mathrm{CFU} \mathrm{g} \mathrm{g}^{-1}\right.$ of soil $)$ over all other treatments except treatments receiving rock phosphate @ 100 and 150 kg $\mathrm{ha}^{-1}$ to the preceding sunhemp (31.93 and $33.79 \times 10^{4} \mathrm{CFU} \mathrm{g}^{-1}$ of soil) and $\mathrm{RDF}+\mathrm{FYM}$ to both sunhemp and bajra crops in the system (33.64 $\times 10^{4} \mathrm{CFU} \mathrm{\textrm {g } ^ { - 1 }}$ of soil). Application of rock phosphate@ $@ 50 \mathrm{~kg} \mathrm{ha}^{-1}$ to the preceding bajra recorded significantly lower number of fungal colonies $\left(25.8 \times 10^{4} \mathrm{CFU} \mathrm{g}^{-1}\right.$ of soil $)$ as compared to all other treatments. Application of rock phosphate @ $200 \mathrm{~kg} \mathrm{ha}^{-1}$ to the preceding sunhemp recorded significantly higher free living $\mathrm{N}_{2}$ fixers population (53.23 $\times 10^{3} \mathrm{CFU} \mathrm{g}^{-1}$ soil) which inturn was on par with treatments receiving rock phosphate @ $150 \mathrm{~kg} \mathrm{ha}^{-1}$ to the preceding sunhemp $(51.23$ $\times 10^{3} \mathrm{CFU} \mathrm{g}^{-1}$ soil) and RDF + FYM to both the crops in the system $\left(50.08 \times 10^{3} \mathrm{CFU} \mathrm{g}^{-1}\right.$ soil). Significantly lower number of free living $\mathrm{N}_{2}$ fixers was recorded with rock phosphate application @ $50 \mathrm{~kg} \mathrm{ha}^{-1}$ to the preceding bajra crop $\left(53.9 \times 10^{3} \mathrm{CFU} \mathrm{g}^{-1}\right.$ soil $)$ and was on par with rock phosphate application@ 100 and $150 \mathrm{~kg} \mathrm{ha}^{-1}$ to the preceding bajra crop (57.6 and $58.0 \times 10^{3}$ CFU g ${ }^{-1}$ soil). Application of RDF + FYM (26.92 $10^{3}$ CFU $\mathrm{g}^{-1}$ of soil) to bajra and groundnut crops in the system recorded significantly higher number of phosphorus solubilizers colonies and it was on par with treatments receiving rock phosphate@100 $\mathrm{kg} \mathrm{ha}^{-1}\left(24.6410^{3} \mathrm{CFU} \mathrm{g} \mathrm{g}^{-1}\right.$ of soil) to the preceding sunhemp. This could be attributed to release higher amounts of root exudates, supporting numerous and diverse micro flora.

\section{How to cite this article:}

Mallesha and Satyanarayana Rao. 2017. Effect of Phosphorus Management through Rock Phosphate Application to Preceding Crops on Soil Enzymes and Microbial Biomass in Organic Cultivation of Groundnut. Int.J.Curr.Microbiol.App.Sci. 6(9): 479-482.

doi: https://doi.org/10.20546/ijcmas.2017.609.057
Similar results were also recorded by Meena and Biswas (2013) where in, application of rock phosphate enriched compost (RPEC) as well as recommended dose of fertilizers applied either alone or in combination in wheat-soybean cropping system significantly improved microbial biomass $\mathrm{P}$ and alkaline phosphatase activity in surface $(0-15 \mathrm{~cm})$ and sub-surface $(15-30 \mathrm{~cm})$ soil, than unfertilized control plot after harvest of wheat.

\section{References}

Casida, L., Klein, D. and Santoro, T., 1964, Soil dehydrogenase activity. Soil Sci., 98: 371-376.

Evazi, Z., and Tabatabai, M. A., 1979, Phosphatase in soils. Soil Biol. Biochem., 9: 167-172.

Meena, M. D., and Biswas, D. R., 2013. Residual effect of rock phosphate and waste mica enriched compost on yield and nutrient uptake by soybean. Legume Res. 36(5): 406-413.

Nazeer, M., and Muhammad, D., 2014, Direct and residual effect of hazara rock phosphate (HRP) on wheat and succeeding maize in alkaline calcareous soils. Pak. J. Bot., 46(5): 1755-1761.

Okello, D. K., Biruma, M. and. Deom, C. M., 2010. Overview of groundnuts research in Uganda: Past, present and future. African J. Biotechnol. 9(39): 64486459.

Pramer, D., and Schmidt, E. L., 1964, Experimental soil microbiology. Burgers Pub. Minneapolis, Minnesota, USA. 